\title{
VII. On the combustion of the human body, produced by the long and immoderate use of spirituous liquors
}

\section{Pierre-Aime Lair}

To cite this article: Pierre-Aime Lair (1800) VII. On the combustion of the human body, produced by the long and immoderate use of spirituous liquors, Philosophical Magazine Series 1, 6:22, 132-146, DOI: 10.1080/14786440008677201

To link to this article: http://dx.doi.org/10.1080/14786440008677201

曲 Published online: 18 May 2009.

Submit your article to this journal $\pi$

Џ Article views: 5

Q View related articles $\longleftarrow$ 
tion. 5. When the moleculæ of caloric are accumulated in that body, they are thrown off from it by the force of repulfion; and from this refults the fublime harmony of attraction and repulfion, the only caufe of the equilibrium of the univerfe.

[To be continued.]

VII. On the Combuftion of the Human Body, produced by the long and immoderate Ufe of Spirituous Liquors. By Pierre-Aime Lair*.

N natural as well as civil hiftory there are facts prefented to the meditation of the obferver, which, though confirmed by the moft convincing teftimony, feem on the firft view to be deftitute of probability. Of this kind is that of people confumed by coming into contact with common fire, and of their bodies being reduced to ahes. How can we conceive that fire, in certain circumftances, can exercife fo powerful an action on the human body as to produce this effect? One might be induced to give lefs faith to thefe inftances of combuftion as they feem to be rare. I confers that at firft they appeared to me worthy of very little credit, but they are prefented to the public as true by men whofe veracity feems un. queftionable. Bianchini, Maffei, Rolli, Le Cat, Vicq-d'Azyr, and feveral men diftinguihed by their learning, have given certain teftimony of the fasts. Befides, is it more furprifing to experience fush incineration than to void faccharine urine, or to fee the bones foftened to fuch a denrec as to be reduced to the ftate of a jelly? The effers of this combuftion are certainly not more wonderful than thofe of the bones foftened, or of the diabetes mellitus. This morbific difpofition, therefore, would be one more foourge to afflict humanity; but in phyifes, facts being always preferable to reafoning, I hall here collect thofe which appear to me to bear the impreffion of truth; and, left I fhould alter the fenfe, I fhall quote them fuch as they are given in the works from which I have extracted them.

We read in the Tranfactions of Copenhagen, that in $16 y$ :

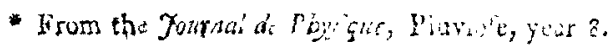


a woman of the lower clafs, who for three years had ufed fpirituous liquors to fuch excefs that he would take no other nourifhment, having fat down one evening on a ftraw chair to fleep, was confumed in the night-time, fo that next morning no part of her was found but the fkull and the extreme joints of the fingers; all the reft of her body, fays Jacobæus, was reduced to athes.

The following extract of the memoir of Bianchini is taken from the Annual Regifter for $176_{3}$ :-The Countefs Cornelia Bandi, of the town of Cefena, aged 62, enjoyed a good ftate of health. One evening, having experienced a fort of drowfinefs, the retired to bed, and her maid remained with her till the fell aneep. Next morning, when the girl entered to awaken her miltreis, fhe found nothing but the remains of her body in the mot horrid condition. At the diftance of four feet from the bed was a heap of athes, in which could be diftinguifhed the legs and arms untouched. Between the legs lay the head, the brain of which, together with half the pofterior part of the cranium, and the whole chin, had been confumed: three fingers were found in the fate of a coal; the reft of the body was reduced to afhes, which, when wouched, left on the fingers a fat, foetid moifture. A Imall lamp which ftood on the floor was covercd with afhes, and contained no oil; the tallow of two candles was melted on a table, but the wicks ftill remained, and the fect of the candlefticks were covered with a certain moifure. The bed wis not damaged; the bed-clothes and coverlid were raifed up and thrown on one fide, as is the cafe when a perfon gets up. The furniture and tapeftry were covered with a moift kind of foot of the colour of afhes, which had penetrated into the drawers and dirtied the linen. This foot having been conveyed to a neighbouring kitchen, adhered to the walls and the utenfils. A piece of bread in the cupboard was covered with it, and no dog would touch it. The infectious odour had been communicated to other apartments. The Annual Regiter fates, that the Countefs of Cufena was accuftomed to bathe all her boly in camphorated fpirit of wine. Bianehini caufed the details of this deplorable event to be publihed at the time whon it took place, and no one con-

tradicted 
tradicted them. It was attefted alfo by Scipio Maffei, a learned cotemporary of Bianchini, who was far from being credulous; and, in the laft place, this furprifing fact was confirmed to the Royal Society of London by Paul Rolli. The Annual Regifter mentions alfo two other facts of the fame kind which occurred in England, one at Southampton and the other at Coventry.

An inftance of the like kind is preferved in the fame work * in a letter of $\mathrm{Mr}$. Wilmer, furgeon _- " Mary Clues, aged 50 , was much addicted to intoxication. Her propenfity to this vice had increafed after the death of her hußband, which happened a year and a half before. For about a year, fcarcely a day had pafted in the courfe of which the did not drink at leaft half a pint of rum or anifeed-water. Her health gradually declined, and about the beginning of February the was attacked by the jaundice and confined to her bed. Though the was incapable of much action, and not in a condition to work, fhe fill continued her old habit of drinking every day and fmoking a pipe of tobacco. The bed in which the lay ftood parallel to the chimney of the apartment, and at the diftance from it of about three feet. On Saturday morning, the ift of March, fhe fell on the lloor; and her extreme weaknefs having prevented her from getting up, the remained in that fate till fome one entered and put her to bed. The following night the wihed to be left alone. A woman quitted her at haif after eleven, and, according to cuftom, thut the door and locked it. She had put on the fire two large pieces of coal, and placed a light in a candleftick on a chair at the head of her bed. At half after five in the morning a fmoke was feen iffuing through the window, and the door bcing fpeedily broke open, fome flames which were in the room were foon extinguifhed. Between the bed and the chimmey were found the remains of the unfortunate Clues: one leg and a thigh were fill entire; but there remained nothing of the $\mathrm{kin}$, the mufcles, and the vicera. The bones of the cranium, the breatt, the fpine, and the upper cxtremities, were entirely calcined, and covered with a whitith efforefcence. The people were mull

\footnotetext{
* Annuab Ruginer for 5773, p. 73 .
} 
furprifed that the furniture had fuftained fo little injury. The fide of the bed which was next to the chimney had fuffered the mof; the wood of it was lightly burnt; but the featherbed, the clothes, and covering, were fafe. I entered the apartment about two hours after it had been opened, and obferved that the walls and every thing in it were blackened; that it was filled with a very difagreeable vapour; but tirat nothing except the body exhibited any ftrong traces of fire."

This infance has great fimilarity to that related by Vicqd'Azyr in the Encyclopedic Metbodique, under the head, Pathologic Anatomy of Man. A woman, about fifty years of age, who indulged to excefs in fpirituous liquors, and got drunk every day before the went to bed, was found entirely burnt, and reduced to afhes. Some of the offeous parts only were left, but the furniture of the apartment had fuffered very little damage. Vicq-d'Azyr, inftead of difbelieving this phenomenon, adds, that there have been many other inftances of the like kind.

We find alfo a circumftance of this kind in a work entitied, Acta Medica et pbilofopbica Hafrienfia; and in the work of Henry Bohanfer, entitled, Le nonewern phofploore anflammé. A woman at Paris, who had been accuttomed, for three years, to drink fpirit of wine to fuch a degree that the ufed no other liquor, was one day found entirely reduced to afhes, except the fkull and extremitics of the fingers.

The Tranfactions of the Royal Socicty of London profent alfo an inftance of human combuftion no lefs extraordinary: It was mentioned at the time it happoned in all the joumals; it was then attefted by a great number of eye-witneffes, and became the fubject of many learned difcufions. Throe accounts of this event, by different authors, all nearly comeicic. The fact is related as follows:- "Grace Pitt, the wife of a fifhmonger of the parifh of St. Clement, Ipfwich, aged about. fixty, had contracted a habit, which the continued for feveral years, of coming down every night from her bed-room, half drefted, to moke a pipe. On the night of the $9^{\text {th }}$ of April 1744, fhe got up from bed as ufual. Her daughter, who nept with her, did not perceive the was abfent till next morning when the awoke, foon after which the put on her 


\section{$\pm 36$}

lothes, and going down to the kitchen, found her mother ftretched out on the right fide, with her head near the grate; the body extended on the hearth, with the legs on the floor, which was of deal, having the appearance of a log of wood, confumed by a fire without apparent flame. On beholding this fpcotacle, the girl ran in great hafte and poured over her mother's body fome water contained in two large veffels in order to extinguifh the fire; while the foetid odour and fmoke which exhaled from the body almoft fuffocated fome of the neighbours who bad haftened to the girl's affiftance. The trunk was in fome meafure incinerated, and refembled a heap of coals covered with white athes. The head, the arms, the legs, and the thighs, had alfo participated in the burning. This woman, it is faid, had drunk a large quantity of fpirituous liquor in confequence of being overjoyed to hear that one of her daughters had returned from Gibraltar. There was no fire in the grate, and the candle had burnt entirely out in the focket of the candluftich, which was clofe to her. Beficles, there were found near the confumed body the clothes of a child and a paper foreen, which had futtained no injury by the fire. The drefs of this woman confinted of a cotton gorn.

Le Cat, in a memoir on fpontaneous burning, mentions feveral other infances of combultion of the human body. "Haring," fays he, "fpent feveral months at Rheims in the years I724 and 1725 , I lodged at the houfe of Sieur Nillet, whofe wife got intoxicated every day. The domeftic conomy of the family was manased by a pretty young girl, which I muft not omit to remark, in order that all the circumfiances which accompanicd the fuct $I$ am about to relate, may be better undertuod. This woman was found confumed on the 20th of February $1 \% 25$, at the diftance of $a$ foot and a half from the hearh in her kitchen. A part of the head only, with a portion of the lower extremities and a few of the vertebre, had chipte cimbution. A foot and a half of the flooring under the Lody had been comfumed, but a kneading-trough and a powdering-tub, which were very near the body, had fuftained no injury. M. Chretien, a furgeon, cxamind the remains of the body with every 
juridical formality. Jean Millet, the hurband, being interrogated by the judges who inftituted an inquiry into the affatr, declared, that about eight in the evening on the $1 g^{\text {th }}$ of February he had retired to reft with his wife, who not being able to fleep, had gone into the kitchen, where he thought the was warming herfelf; that, having fallen afleep, he was wakened about two o'clock by an infectious odour, and that, having run to the kitchen, he found the remains of his wife in the ftate defcribed in the report of the phyficians and furocons. The judges having no fufpicion of the real caufe of this event, profecuted the affair with the utinoft diligence. It was very unfortmate for Millet that he had a handiome fervant-maid, for neither his probity nor innocence was able to fave him from the fufpicion of having got rid of his wife by a concerted plot, and of having arranged the reft of the circumftance in fuch a manner as to give it the appearance of an accident. He experienced, therefore, the whole feverity of the law; and though, by an appeal to 2 fuperior and very enlightened court, which difcovered the caufe of the combution, he came off victorious, he fuffered fo much from uneafinefs of mind, that he was obliged to pafs the remainder of his melancholy days in an hofpital.",

Lc Cat relutes another inftance, which has a moft perfect refemblance to the preceding:- " $M$. Boinneau, cure of Plerguer, near Dol," fays he, "wrote to me the following letter, dated February 22, 1749 : Allow me to communicate to you a fadt which took place here about a fortnight ago. Madame de Boifeon, 80 years of agé, exceedingly meagre, who had drunk nothing but fpirits for feveral years, was fitting in her elbow-chair before the fire while her waitingniaid went out of the room for a few moments. On her return, feeing her miltrefs on fire, the immediately gave an alarm, and fome people having come to her affifance, one of them endaavoured to extinguifh the flames with his hand, but they adhered to it as if it had been dipped in brandy or oil on fire. Water was brought and thrown on the lady in abundance, yet the firt appeared more violent, and was not extinguifhed till the whole flefh had been confumed. Her fkeleton, exceedingly black, remained entire in the chair, Vot. VI. 
which was only a little fcorched; one leg only, and the two hands, detached themfelves from the reft of the bones. It is not known whether her clothes had caught fire by approaching the grate. The lady was in the fame place in which fhe fat every day; there was no extraordinary fire, and the had not fallen. What makes me fufpect that the ufe of fpirits might have produced this effect is, that I have been affured, that at the gate of Dinan an accident of the like kind happened to another woman under fimilar circumfances."

To thefe inftances, which I have multiplied to ftrengthen the evidence, I thall add two other facts, of the fame kind, publifhed in the Journal de Medicine*. The firt took place at Aix, in Provence, and is thus related by Muraire, a furgeon:- "In the month of February 1779, Mary Jauffet, widow of Nicholas Gravier, thoemaker, of a fmall fize, exceedingly corpulent, and addicted to drinking, having been burnt in her apartment, M. Rocas, my colleague, who was commiffioned to make a report refpecting the remains of her body, found only a mals of afhes, and a few bones, calcined in fuch a manner that on the leaft preffure they were reduced to duft. The bones of the cranium, one hand, and a foot, had in part efcaped the action of the fire. Near thefe remains ftood a table untouched, and under the table a fmall wooden ftove, the grating of which, having been long burnt, afforded an aperture, through which, it is probable, the fire that occafioned the melancholy accident had been communicated: one chair, which ftood too near the flames, had the feat and fore-feet burnt. In other refpects, there was no appearance of fire either in the chimney or the apartment; fo that, except the fore-part of the chair, it appears to me that no other combultible matter contributed to this fpeedy incineration, which was effected in the fpace of feven or eight hours."

The other inftance, mentioned in the Journal de Medicine $\ddagger$, took place at Caen, and is thus related by Merille, a furgeon of that city, fill alive:- "Being requefted, on the $3 \mathrm{~d}$ of June 1782 , by the king's officers, to draw up a report of the ftate in which I found Mademoifelle Thuars, who

$$
\text { * Vol. LIX. p. } 440 \text {. t Vol. LIX. p. } 140 \text {. }
$$


was faid to have been burnt, I made the following obfervations:-The body lay with the crown of the head refting againft one of the andirons, at the diftance of eighteen inches from the fire; the remainder of the body was placed obliquely before the chimney, the whole being nothing but a mafs of athes. Even the molt folid bones had loft their form and confiftence; none of them could be diftinguifhed except the coronal, the two parietal bones, the two lombar vertebra, a portion of the tibia, and a part of the omoplate; and thefe, even, were fo calcined, that they became duft by the leaft preffure. The right foot was found entire, and fcorched at its upper junction; the left was more burnt. The day had been cold, but there was nothing in the grate except two or three bits of wood, about an inch in diameter, burnt in the middle. None of the furniture in the apartment was damaged. The chair on which Mademoifelle Thuars had been fitting, was found at the diftance of a foot from her, and abfolutely untouched. I muft here obferve, that this lady was exceedingly corpulent; that the was above fixty years of age, and much addicted to fpirituous liquors; that the day even of her death he had drunk three bottles of wine and about a bottle of brandy; and that the confumption of the body had taken place in lefs than feven hours, though, according to appearance, nothing around the body was burnt but the clothes."

The town of Caen affords feveral other inftances of the fame kind. I have been told by many people, and particularly a phyfician of Argentan, named Bouffet, author of an Effay on Intermittent Fevers, that a woman of the lower clafs, who lived at Placc Villars, and who was known to be much addicted to ftrong liquor, had been found in her houfe burnt. The extremities of her body only were fpared, but the furniture was very little damaged.

A like unfortunate accident happened alfo at Caen to another old woman addicted to drinking. I was affured by thofe who told me the fact, that the flames which proceeded from the body could not be extinguifhed by water; but I think it needlefs to relate the particulars of this and of another fimilar event which took place in the fame town, be- 


\section{I40 On the Cambuflian of the Human Budy,}

caufe, as they were not attefted by a proces-verbal, and not having been communicated by profeftional men, they do not infpire the fame confidence.

This collection of initances is fupported, therefore, by all thofe authentic proofs which can be reyuired to form human teftimony; for, while we admit the prudent doubt of Defeartes, we ought to reject the univerfal doubt of the Pyrrhonifts. The multiplicity and uniformity even of thefe facts, which occurred in different places, and were attefted by fo many enlightened men, carry with them convistion; they have fuch a relation to each other that we are inclined to aferibe them to the fame caufe.

I. The perfons who experienced the effects of this combuftion had for a long time made an immoderate ufe of fpirituous liquors.

2. The combuftion took place only in women.

3. Thefe women were far advanced in life.

4. Their bodies did not take fire fpontaneouny, but were burnt by accident.

5. The extremities, fuch as the feet and the hands, were generally fpared by the fire.

6. Water fometimes, inftead of extinguilling the flames which proceeded from the parts on fire, gave them more activity.

7. The fire did very little danage, and ofien even fpared the combuftible objects which were in contact with the buman body at the moment when it was burning.

8. The combuntion of thefe bodies left as a refiduum fat foetid ahes, with an unctuous, ftinking, and very penetrating foot.

Let us now enter into an examination of thefe eight general obfervations.

The firt idea which occurs on reading the numerous inftances of human combuftion above related is, that thofe who fell victims to thofe fatal accidents were almoft all addicted to fpirituous liquors. The woman mentioned in the. Tranfactions of Copenhagen had for three years made fuch an in moderate ufe of them that fhe would take no other nourithment. Mary Clues, for a year before the accident happenced, had fcarcely been a fingle day without drinking half a pint 
of rum or of anifeed-water. The wife of Millet had beem continually intoxicated; Madam de Boifeon for feveral ycars had drunk nothing but fpirits; Mary Jauffret was much addicted to drinking; and Mademoifelle Thuars, and the other women of Caen, were equally fond of ftrong liquors.

Such excefs, in regard to the ufe of fpirituous liquors, muft have had a powerful action on the bodies of the perfons to whom I allude. All their fluids and folids muft have experienced its fatal influence; for the property. of the abforbing velfels, which is fo active in the human body, feems on this occafron to have acted a diftinguithed part. It has been obferved that the urine of great drinkers is generally aqueous and limpid. It appears, that in drunkards who make an immoderate ufe of fpirituous liquors, the aqueous part of their drink is difcharged by the urinary paffage, while the alcoholic, almoft like the volatile part of aromatic fubftances, not being fubjected to an entire deeompofition, is abforbad into every part of their bodies.

I thall now proceed to the fecond general obfervation. that the combuftion took place only in women.

I will not pretend to affert that men are not liable to combuftion in the fame manner, but I have never yet been able to find one well certified inftance of fuch an event; and 25 we cannot proceed with any certainty but on the anthority of facts, I think this fingularity fo furprifing as to give rife to a few reflections. Perhaps when the caufe is examined, it will appear perfectly natural. The female body is. in general more delicate than that of the other fex. 'The fyftem of their folids is more relaxed; their fibres are more fragile and of a weaker ftructure, and therefore their texture more eafily hurt. Their mode of life alfo contributes to increafe the weaknefs of their organization. Women, abandoned in general to a fedentary life, charged with the care of the internal domeftic economy, and often thut up in clofe apartments, where they are condemped to fpend whole days without tak. ing any exercife, are more fubject than men to become corpulent. The texture of the foft parts in female bodies being more fpongy, abforption ought to be freer; and as their 
whole bodies imbibe fpirituous liquors with more eafe, they ought to experience more readily the impreffion of fire. Hence that combuftion, the melancholy inftances of which feem to be furnithed by women alone; and it is owing merely to the want of a certain concurrence of circumpances and of phyfical caufes, that thefe events, though lefs rare than is fuppofed, do not become more common.

The fecond general obfervation ferves to explain the third; I mean, that the combuftion took place only in women far advanced in life. The Countefs of Cefena was fixty-two years of age; Mary Clues, fifty-two; Grace Pitt, fixty; Madame de Boifeon, eighty; and Mademoifelle Thuars more than fixty. Thefe examples prove that combuftion is more frequent among old women. Young perfons, diftracted by other paffions, are not much addicted to drinking; but when love, departing along with youth, leaves a vacuum in the mind, if its place be not fupplied by ambition or in. tereft, a tafte for gaming, or religious fervor, it generally falls a prey to intoxication. This paffion ftill increafes as the others diminith, efpecially in women, who can indulge it without reftraint. Wilmer, therefore, obferves, "that the propenfity of Mary Clues to this vice had always increafed after the death of her hufband, which happened about a year before:" almoft all the other women of whom I have fpoken, being equally unconfined in regard to their actions, could gratify their attachment to fpirituous liquors without oppofition.

It may have been obferved that the obefity of women, as they advance in life, renders them more fedentary; and if, as has been remarked by Baumes*, a fedentary life overcharges the body with hydrogen, this effect muft be ftill more fenfible among old women. Dancing and walking, which form falutary recreation for young perfons, are at 2 certain age interdicted as much by nature as by prejudice. It needs therefore excite no aftonifhment that old women, who are in general more corpulent and more addicted to drinking, and who are often motionlefs like inanimate

* Effai du Syftume Chemique de la Science de l'Homme. 
maffes, during the moment of intoxication, thould experence the effects of combuftion.

Perhaps we have no occafion to go very far to fearch for the caufe of thefe combuftions. The fire of the wooden ftove, the chimney, or of the candle, might have been communicated to the clothes, and might have in this manner burnt the perfons above mentioned, on account of the peculiar difpofition of their bodies. Maffei obferves that the Countefs of Cefena was accuftomed to bathe her whole body with fpirit of wine. The vicinity of the candle and lamp, which were found near the remains of her body, occafioned, without doubt, the combuftion. This accident reminds us of that which happened to Charles II. king of Navarre. This prince, being addicted to drunkennefs and exceffes of every kind, had caufed himfelf to be wrapped up in cloths dipped in fpirits, in order to revive the natural heat of his body which had been weakened by debauchery; but the cloths caught fire while his attendants were faftening them, and he perifhed a victim to his imprudence.

Befides accidental combution, it remains for us to examine whether fpontaneous combution of the human body can take place, as afferted by Le Cat. Spontaneous combuftion is the burning of the human body without the contact of any fubftance in a ftate of ignition. Nature, indeed, affords feveral inftances of fpontancous comburtion in the mineral and vegetable kingdoms. The decompofition of pyrites, and the fubterranean proceffes which are carried on in volcanoes, afford proofs of it. Coal-mines may readily take fire fpontaneoully; and this has been found to be the caie with heaps of coals depofited in clofe places. It is by a fermentation of this kind that dunghills fometimes become hot, and take fire. This may ferve alfo to explain why truffes of hay, carried home during moift weather, and piled up on each other, fometimes take fire. But, can fpontaneous combuftion take place in the human body? If fome authors are to be credited *, very violent combuftion may be produced in our bodies by nature and by artificial proceffes. Sturmius $\dagger$ fays that in the northern countries flames often burft from

- German Ephemerides, Obfery. 77. t Ibid. Tenth year, p. ss. 


\section{On the Combuftion of the Human Body,}

the ftomach of perfons in a tate of intoxication. Three noblemen of Courland having laid a bet which of them could drink molt fpirits, two of them died in confequence of fuffocation by the flames which iffued with great violence from their ftomachs. We are told by Thomas Bartholin *, on the authority of Vorftius, that a foldier, who had drutik. two glaffes of fpirits, died after an eruption of flames from his mouth. In his third century Bartholin mentions another accident of the fame kind after a drinking-match of frong liquor.

It now remains to decide, from thefe inftances, refpecting the accidental or fpontancous caufes which produce combuftion, Nature, by affuming a thoufand different forms, feems at firft as if defirous to elude our obfervation; but, on mature reffection, if it be found eafy to prove accidental combution, fpontaneous combuftion appears altogether improbable; for, even admitting the inftances of people fuffocated by flames which iffued from their mouths, this is Atill far from the combuftion of the whole body. There is a great difference between this femi-combuftion and fpontaneo:1s combuftion fo complete as to reduce the body to aflues, as in the cafes above mentioner. As the human body has never been feen to experience total combution, thefe affertions feem rather the productions of a fervid imagination than of real obfervation; and it too often happens that Nature in her mode of action does not adopt our manner of feeing.

I thall not extend further thefe obfervations on the combuftion of the human body, as I Hatter myfelf that after this examination every perfon muft be ftruck with the relation which exifts between the caufe of this phenomenon and the effects that enfue. A fyftem embellihed with imaginary charms is often feducing, but it never prefents a perfect whole. We have feen facts juftify reafoning, and reafoning ferve afterwards to explain facts. The combuftion of the human body, which on the firft view appears to have in it fomething of the marvellous, when explained, exhibits nothing but the utmoft fimplicity: fo true it is, that the wonderful is often produced by effects which, as they rarely ftrike

* Firf century. 
our eyes, permit our minds fo much the lefs to difcover their real caufe.

Some people, however, may afcribe to the wickednefs of mankind what we afcribe to accident. It may be faid, that affaffins, after putting to death their unfortunate victims, rubbed over their bodies with combultible fubftances, by which they were confumed. But even if fuch an idea fhould ever be conceived, it would be impoffible to carry it into execution. Formerly, when criminals were condemned to the flames, what a quantity of combuftible fubftances was neceffary to burn their bodies! A baker's boy, named Renaud, being condemned to be burnt a few ycars ago at Caen, two large cart-loads of faggots were required to confume the body, and at the end of more than ten hours fome remains of the bones were ftill to be feen. What proves that the combuftion in the before-mentioned inftances was. not artificial is, that people often arrived at the moment when it had taken place, and that the body was found in its natural ftate. People entered the houfe of Madame Boifeon at the time when her body was on fire, and all the neighbours faw it. Befides, the people of whom I have fpoken were almoft all of the loweft clafs, and not nuch calculated to give rife to the commiffion of fuch a crime. The woman mentioned in the Tranfactions of Copenhagen was of the pooreft condition; Grace Pitt was the wife of a filhmonger; Mary Jauffet that of a thoemaker; and two other women, who refided at Caen, belonged to the loweft order of fociety. It is inconteftible, then, that in the inftances I have adduced the combultion was always accidental and never intentional.

It may be feen that a knowledge of the caufs of this phenomenon is no lefs interefting to criminal juttice than to natural hiftory, for unjuft fufpicions may fometimes $f_{\mathfrak{d}}$ ll on an innocent man. Who will not thudder on recollecting the cafe of the unfortunate inhabitant of Rheims, who, afier having loft his wife by the effect of combuftion, was in danger of perithing himfelf on the fcaffold, condemned unjuftly by an ignorant tribunal!

I fhall confider myleff happy if this picture of the fatal effects of intoxication makes an imprefion on thofe addieted VoL. VI. 
to this vice, and particularly on women, who moft frequently become the victims of it. Perhaps the frightful details of fo horrid an evil as that of combuftion will reclaim drunkards from this horrid practice. Plutarch relates, that at Sparta children were deterred from drunkennefs by exhibiting to them the fpectacle of intoxicated naves, who, by their hideous contorfions, filled the minds of thefe young fpectators with to much contempt that they never afterwards got drunk. This ftate of drunkennefs, however, was only tranfitory. How much more horrid it appears in thofe unfortunate victims confumed by the flames and reduced to afhes! May men never forget that the vine fometimes produces very bitter fruit-difeafe, pain, repentance, and death!

VIII. Meteorological Axioms, by L. Cотте; or the general Refult of bis own and foreign Metcorological Objervations during the courfe of Thirty $Y_{\text {ears }}$ 。

$\mathrm{O}$

UR metcorological obfervations are as old as the eftablinment of the Academy of Sciences in the year 1666 , and have never yet becn interrupted. The mon celebrated academicians, fuch as a Sidileau, a de la Hire, a Maraldi, a Cafini, a Fouchy, a Chappe, \&c. have contributed towards them; and feveral members, fuch as Morin, Duhamel, Malovin, Neffer, \&c. paid attention to the fame object without making themfelves much known. The correfpondents of the Academy alfo frequently communicated to it their meteorological obfervations. All the learned focieties in Europe comprehend meteorology in the lift of their labours, and particularly the Royal Society of London, the Academies of Berlin, Stuclholm, leterfourg, \&c. but, above all, the Medical Socicties at Paris and the Hague, and the Mctcorologic Society at Manhein. Thefe three learned bodies have therefore the moft extenfive correfpondence.

I have communicated to the pullic the refult of the obfervations made by all thefe focieties as well as of my own

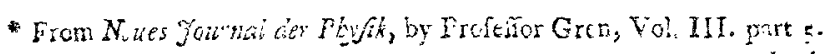

during 